\title{
Blood-brain barrier-associated pericytes internalize and clear aggregated amyloid- $\beta 42$ by LRP1-dependent apolipoprotein E isoform-specific mechanism
}

Qingyi Ma ${ }^{1,2 \dagger}$, Zhen Zhao ${ }^{1 \dagger}$, Abhay P Sagare ${ }^{1 \dagger}$, Yingxi Wu' ${ }^{1}$ Min Wang ${ }^{1}$, Nelly Chuqui Owens ${ }^{1}$, Philip B Verghese ${ }^{3}$, Joachim Herz ${ }^{4,5,6}$, David M Holtzman ${ }^{7}$ and Berislav V Zlokovic ${ }^{1^{*}}$

\begin{abstract}
Background: Clearance at the blood-brain barrier (BBB) plays an important role in removal of Alzheimer's amyloid- $\beta$ (A $\beta$ ) toxin from brain both in humans and animal models. Apolipoprotein $E$ (apoE), the major genetic risk factor for $A D$, disrupts A $\beta$ clearance at the BBB. The cellular and molecular mechanisms, however, still remain unclear, particularly whether the BBBassociated brain capillary pericytes can contribute to removal of aggregated $A \beta$ from brain capillaries, and whether removal of $A \beta$ aggregates by pericytes requires apoE, and if so, is $A \beta$ clearance on pericytes apoE isoform-specific.
\end{abstract}

Methods: We performed immunostaining for $A \beta$ and pericyte biomarkers on brain capillaries ( $<6 \mu \mathrm{m}$ in diameter) on tissue sections derived from AD patients and age-matched controls, and APP ${ }^{\text {Swe/0 }}$ mice and littermate controls. Human Cy3-A 342 uptake by pericytes was studied on freshly isolated brain slices from control mice, pericyte LRP1-deficient mice (L $r p^{10 x / l o x}$; Cspg4-Cre) and littermate controls. Clearance of aggregated Aß42 by mouse pericytes was studied on multi-spot glass slides under different experimental conditions including pharmacologic and/or genetic inhibition of the low density lipoprotein receptor related protein 1 (LRP1), an apoE receptor, and/or silencing mouse endogenous Apoe in the presence and absence of human astrocyte-derived lipidated apoE3 or apoE4. Student's t-test and one-way ANOVA followed by Bonferroni's posthoc test were used for statistical analysis.

Results: First, we found that 35\% and 60\% of brain capillary pericytes accumulate A $\beta$ in AD patients and 8.5 -month-old $A P P^{S W / O}$ mice, respectively, compared to negligible uptake in controls. Cy3-A 42 species were abundantly taken up by pericytes on cultured mouse brain slices via LRP1, as shown by both pharmacologic and genetic inhibition of LRP1 in pericytes. Mouse pericytes vigorously cleared aggregated Cy3-A 342 from multi-spot glass slides via LRP1, which was inhibited by pharmacologic and/or genetic knockdown of mouse endogenous apoE. Human astrocyte-derived lipidated apoE3, but not apoE4, normalized AB42 clearance by mouse pericytes with silenced mouse apoE.

Conclusions: Our data suggest that BBB-associated pericytes clear Aß aggregates via an LRP1/apoE isoform-specific mechanism. These data support the role of LRP1/apoE interactions on pericytes as a potential therapeutic target for controlling $A \beta$ clearance in AD.

Keywords: Pericyte, Blood-brain barrier (BBB), Amyloid- $\beta$ clearance, Low-density lipoprotein receptor-related protein 1 (LRP1), Apolipoprotein E

\footnotetext{
* Correspondence: zlokovic@usc.edu

${ }^{\dagger}$ Qingyi Ma, Zhen Zhao and Abhay P Sagare contributed equally to this work.

${ }^{1}$ Center for Neurodegeneration and Regeneration, Zilkha Neurogenetic Institute and Department of Physiology and Neuroscience, Keck School of Medicine,

University of Southern California, Los Angeles, California 90033, USA

Full list of author information is available at the end of the article
}

(c) The Author(s). 2018 Open Access This article is distributed under the terms of the Creative Commons Attribution 4.0 International License (http://creativecommons.org/licenses/by/4.0/), which permits unrestricted use, distribution, and reproduction in any medium, provided you give appropriate credit to the original author(s) and the source, provide a link to the Creative Commons license, and indicate if changes were made. The Creative Commons Public Domain Dedication waiver (http://creativecommons.org/publicdomain/zero/1.0/) applies to the data made available in this article, unless otherwise stated. 


\section{Background}

Alzheimer's disease (AD) is a progressive neurodegenerative disorder associated with cognitive impairment, early neurovascular changes, accumulation of amyloid- $\beta$ (A $\beta)$ and tau pathology, and neuron loss $[1,2]$. According to the amyloid hypothesis, the build-up of $\mathrm{A} \beta$ in the brain parenchyma [3-5] and blood vessels [6-9] is the key event leading to other $\mathrm{AD}$-related pathologies and disease symptoms. In the brain, $A \beta$ is produced by neurons and other cell types, and is constantly removed by several clearance mechanisms. This includes receptor-mediated transport across the blood-brain barrier (BBB) into the peripheral circulation [10], enzyme-mediated $A \beta$ proteolytic degradation [11], removal by glial cells [12], and diffusive transport across the interstitial fluid (ISF) along the perivascular spaces [13-15] leading to drainage by the meningeal lymphatic system $[16,17]$. The imbalances between $A \beta$ production and clearance result in $A \beta$ deposition in the brain [18]. Kinetic studies in patients diagnosed with sporadic $A D$ indicate that faulty $A \beta$ clearance, rather than $A \beta$ overproduction, is critical for accumulation of $A \beta$ in the brain [19]. Moreover, recent transport studies in humans have shown that up to $50 \%$ of the $A \beta$ in the brain is transported across the BBB to blood [20], confirming prior findings in animal models [21, 22].

The endothelial cells of the $\mathrm{BBB}$, and the BBB-associated mural cells - pericytes and vascular smooth muscle cells (VSMCs), and glial cells clear $A \beta$, which can lead to $\mathrm{A} \beta$ transport across the BBB to blood, and/or $A \beta$ degradation by mural cells, astrocytes and/or microglia [10, 18]. The low-density lipoprotein receptor-related protein 1 (LRP1), an apolipoprotein $\mathrm{E}$ (apoE) receptor [23, 24], mediates internalization of soluble $A \beta$ at the abluminal side of the $\operatorname{BBB}[22,25,26]$. This is followed by $A \beta$ transcytosis across the $\mathrm{BBB}$ that is regulated by PICALM (Phosphatidylinositol Binding Clathrin Assembly Protein) and Rab5 and Rab11 small GTPases, ultimately leading to $A \beta$ exocytosis across the luminal side of the BBB and clearance into the blood [27]. Consequently, endothelial-specific deletion of $\operatorname{Lrp} 1$ gene [28] or deletion of Picalm gene from the endothelium [27] lead to accelerated $\mathrm{A} \beta$ pathology in $\mathrm{A} \beta$-precursor protein $(A P P)$ overexpressing mice. VSMCs within the small cerebral arteries also clear A $\beta$ via LRP1 $[29,30]$. Similarly, astrocytes clear deposited $A \beta$ via LRP1, which requires mouse endogenous apoE [31].

Brain capillary pericytes are centrally positioned between brain endothelial cells, astrocytes and neurons [32]. Besides roles in regulating $\mathrm{BBB}$ permeability $[33,34]$ and cerebral blood flow [35], pericytes show strong phagocytic activity associated with clearance of toxic foreign molecules [32], and endogenous proteins [36] including Alzheimer's $A \beta$, which can influence development of $\mathrm{A} \beta$ pathology as shown in APP mouse models [37, 38]. Prior studies have demonstrated that apoE disrupts $\mathrm{A} \beta$ clearance across the mouse BBB [39], specifically, apoE4, which carries major genetic risk for $\mathrm{AD}$ [40-42], had greater disruptive effect than apoE3, which carries lower risk. However, the contribution of BBB-associated pericytes compared to endothelial trans-vascular transport to $\mathrm{A} \beta$ clearance at the $\mathrm{BBB}$ still remains elusive, particularly, whether pericytes can contribute to removal of aggregated $A \beta$ from brain capillaries, which develop cerebral amyloid angiopathy (CAA) in $\mathrm{AD}$ [8], and whether removal of $A \beta$ aggregates by pericytes requires apoE, and if so, is $A \beta$ clearance on pericytes apoE isoform-specific? Here we show that $A \beta$ accumulates in abundance in brain pericytes in $\mathrm{AD}$ and $A P P^{S w / 0}$ mice, suggesting their active role in $A \beta$ removal at the $B B B$. Moreover, we show that pericytes internalize and clear $A \beta$ aggregates by an LRP1/apoE isoform-specific mechanism implying that targeting LRP1/apoE pathway in pericytes has potential to control $\mathrm{A} \beta$ clearance in $\mathrm{AD}$.

\section{Methods \\ Animals}

Mice were housed in plastic cages on a $12 \mathrm{~h}$ light cycle with ad libitum access to water and a standard laboratory diet. All procedures were approved by the Institutional Animal Care and Use Committee at the University of Southern California with National Institutes of Health guidelines. We studied $A P P^{S w / 0}$ mice expressing human APP transgene with the $\mathrm{K} 670 \mathrm{M} / \mathrm{N} 671 \mathrm{~L}$ (Swedish) double-mutation under control of the hamster prion promoter [43]. Lrp ${ }^{l o x / l o x}$ mice [44, 45] were crossed with Cspg4-Cre mice [46] to generate $L r p^{\text {lox/lox }}$;Cspg4-Cre mice with deletions of Lrp1 gene from pericytes and oligodendrocyte progenitor cells. To minimize confounding effects of background heterogeneity all experiments were performed using age-matched littermates. Both, male and female mice were used in the study. All animals were randomized for their genotype information. All experiments were blinded; the operators responsible for experimental procedure and data analysis were blinded and unaware of group allocation throughout the experiments.

\section{Human tissue immunofluorescence analysis}

Written consent was obtained and approved by the University of Rochester Medical Center for all studied human subjects prior to death. The postmortem interval ranged between 4 and $16 \mathrm{~h}$. Postmortem brain tissue samples including frontal cortex (Brodmann area 9/10) were obtained from subjects with a definite diagnosis of $\mathrm{AD}$ confirmed by neuropathological analysis including Braak stages $\geq$ III; CERAD (Consortium to Establish a Registry for Alzheimer's Disease) frequent, and neurologically intact controls with no AD pathology (Braak stages $\leq$ III; CERAD - negative). Six controls and six AD samples were used for the current study. Their demographic and clinical 
features were as we reported previously [47], and shown in Additional file 1: Table S1. Vascular risk factors such as atherosclerosis, hypertension and/or myocardial infarction were present in 4 out $6 \mathrm{AD}$ patients and 6 out of 6 controls. The cause of death in all $\mathrm{AD}$ and control patients was either respiratory failure or cardiac failure. All tissues were paraformaldehyde (PFA)-fixed, paraffin-embedded and cut to $10 \mu \mathrm{m}$ thick slices. Sections were deparaffinized with xylene and rehydrated to distilled water after serial ethanol washes. Subsequently, heat-induced antigen retrieval (HIAR) was performed following Dako's protocol. The tissue sections were then blocked in 5\% donkey serum (Jackson ImmunoResearch, West Grove, PA, USA) containing 0.3\% Triton X-100 (Sigma-Aldrich, St. Louis, MO, USA), and then incubated with the following primary antibodies overnight at $4{ }^{\circ} \mathrm{C}$ : goat anti-human PDGFR $\beta$ (1:100, R\&D Systems, Minneapolis, MN, USA), mouse anti-human aminopeptidase $\mathrm{N}$ (CD13) (1:100, R\&D Systems), rabbit anti-human $A \beta$ (1:100, Cell signaling, Boston, MA, USA). Blood vessels were stained by DyLight 488 Labeled Lycopersicon esculentum (Tomato) Lectin (1:100, Vector Laboratories, Burlingame, CA, USA, \# DL-1174) for $1 \mathrm{~h}$ at room temperature. Species-specific fluorochrome-conjugated secondary antibodies were incubated for $1 \mathrm{~h}$ at room temperature, including Alexa 568-conjugated donkey anti-goat (1:200, Invitrogen), Alexa 568-conjugated donkey anti-mouse (1:200, Invitrogen) and Alexa 647-conjugated donkey anti-rabbit (1:200, Invitrogen). Tissue sections were mounted and coverslipped using fluorescent mounting media (Dako, Carpinteria, CA, USA). All slices were scanned using Zeiss 510 confocal microscopy with Zeiss Apochromat water immersion objectives (Carl Zeiss MicroImaging Inc., Thornwood, NY, USA). All slices were scanned using Zeiss 510 confocal microscopy with Zeiss Apochromat water immersion objectives (Carl Zeiss MicroImaging Inc., Thornwood, NY, USA), with lasers and band-pass filter settings as the following: a 488-nm argon laser to excite Alexa Fluor and Dylight 488, and the emission was collected through a 500-550-nm bp filter; a $543 \mathrm{HeNe}$ laser to excite Alexa Fluor 568 and $\mathrm{Cy} 3$ and the emission was collected through a 560-615-nm bp filter; a 633 HeNe laser to excite Alexa fluor 647 and the emission was collected through a 650-700-nm bp filter.

\section{$A \beta$ uptake on freshly isolated mouse brain cortical slices} Brain slices were prepared from 2-month old C57BL6 mice or $\operatorname{Lrp}^{\text {lox/lox}}$;Cspg4-Cre mice. Following the urethane anesthesia, brains were quickly removed from the cranial cavity and sectioned with McIlwain tissue chopper (Ted Pella, Inc., Redding, CA, USA) into $200 \mu \mathrm{m}$ thick slices containing cortex and hippocampus, as previously described [48]. Slices were recovered for $30 \mathrm{~min}$ in a submersion chamber filled with the per-warmed (at $37^{\circ} \mathrm{C}$ ) artificial cerebrospinal fluid (aCSF; $126 \mathrm{mM} \mathrm{NaCl}$, $2.5 \mathrm{mM} \mathrm{KCl}, 1.25 \mathrm{mM} \mathrm{Na}_{2} \mathrm{PO}_{4}, 26 \mathrm{mM} \mathrm{NaHCO} 3,1 \mathrm{mM}$ $\mathrm{MgCl}_{2}, 2 \mathrm{mM} \mathrm{CaCl}_{2}, 0.5 \mathrm{mM}$ ascorbic acid, $2 \mathrm{mM}$ sodium pyrurate, and $10 \mathrm{mM}$ glucose, saturated with $95 \% \mathrm{O}_{2}$ and $5 \% \mathrm{CO}_{2}$ ). Prior to incubation with aCSF containing $5 \mu \mathrm{g} /$ $\mathrm{ml} \mathrm{Cy3-A \beta 42} \mathrm{for} 30 \mathrm{~min}$, slices were pre-incubated with either non-immune IgG (NI-IgG) or LRP1-specific blocking antibody [22, 29] (anti-LRP1 N20, $50 \mu \mathrm{g} / \mathrm{ml}$; Santa Cruz Biotech., Santa Cruz, CA, USA) for $20 \mathrm{~min}$ at $37{ }^{\circ} \mathrm{C}$. At the end of the experiment, brain slices were washed with phosphate buffer saline (PBS) and fixed with $4 \%$ PFA for $30 \mathrm{~min}$. The same immunostaining procedure as for human brain tissue without antigen retrieval was performed on mouse brain slices. Primary antibodies included goat anti-mouse aminopeptidase $\mathrm{N}$ (CD13) (1:100, R\&D Systems), and goat anti-mouse PDGFR $\beta$ (1:100, R\&D Systems). Secondary antibodies were: Alexa 488-conjugated donkey anti-goat (1:200, Invitrogen). Images were obtained with Zeiss 510 confocal microscopy (Carl Zeiss MicroImaging Inc.) with lasers and band-pass filter settings as described above. The distribution of Cy3-A 342 in pericytes and capillary endothelium was analyzed with the NIH Image J software [49].

\section{Pericyte isolation from the mouse brain, culture and transfection}

Brain capillaries were isolated from mouse cortices pooled from 3 to 4 mouse brains for each biological replicate. In experiments in Figs. 4 and 5, we used 3-4 independent biological replicates (cultures), as indicated in the legends to these respective figures. Capillaries were isolated as we have described previously $[49,50]$. In brief, mouse cortices were macroscopically dissected, and all visible white matter was discarded in ice-cold PBS containing $2 \%$ fetal bovine serum (FBS). The brain was homogenized in PBS containing 2\% FBS and centrifuged at 6,000 g for $15 \mathrm{~min}$ after addition of Dextran (70 kDa, Sigma). The capillary pellet was collected and sequentially filtered through a $45 \mu \mathrm{m}$ cell strainer (BD Falcon). The remaining pellet on top of the $45 \mu \mathrm{m}$ cell strainer was collected in PBS and digested for $12 \mathrm{~h}$ at $37^{\circ} \mathrm{C}$ with collagenase A (Roche, 10103586001), as we previously described. The cells were washed with PBS and then plated in complete medium containing DMEM, $10 \%$ FBS, $1 \%$ non-essential amino acids, $1 \%$ vitamins and $1 \%$ antibiotic/antimycotic on plastic (non-coated) tissue culture plates. After 6 to $12 \mathrm{~h}$ the non-adherent cells were washed away and fresh medium was replaced every 23 days. Cultures were confirmed to be morphological consistent with pericyte cultures and PDGFR $\beta$-positive, SMA-positive, Desmin-positive, GFAP-negative, AQP4negative, MAP2-negative, NeuN-negative, VWF-negative, and Iba1-negative, as previously described [37, 49]. Transfections were performed with Neon transfection system (Invitrogen, Grand Island, NY, USA) following the 
manufacturer's protocol. After optimization, the transfection efficiency with pEGFP plasmid was $>80 \%$. For siRNA transfection, 15 pmol of siRNA in $1 \mu \mathrm{l}$ was electroporated into $1 \times 10^{5}$ cells in a total volume of $10 \mu \mathrm{l}$.

\section{Clearance of aggregated Cy3-A $\beta 42$ by primary mouse brain pericytes}

The multi-spot glass slides (Thermo Scientific, 9991090, Waltham, MA, USA) were coated with Cy3- A $\beta 42[29,51]$ at $1 \mu \mathrm{g}$ per spot without cells or with brain capillary pericytes treated with non-immune IgG (NI-IgG) or LRP1-specific blocking antibody [22, 29] (anti-LRP1; $50 \mu \mathrm{g} /$ $\mathrm{ml}$ ) or) or apoE-specific blocking antibody (anti-apoE, HJ6.3, $50 \mu \mathrm{g} / \mathrm{ml}$ ), scrambled siRNA (si.Control) or LRP1 siRNA (si.Lrp1) (Dharmacon, E-040764-00-0010) or apoE siRNA (si.Apoe) (Dharmacon, E-040885-00-0005), and $500 \mathrm{nM}$ receptor-associated protein (RAP) [52] (EMD Bioscience), lipidated apoE3 (40 nM) or apoE4 (40 nM) [49]. Cells (5,000 per spot) were incubated for 5 days in DMEM containing 10\% heat inactivated FBS, penicillin and streptomycin (Invitrogen). Cells were labeled with Cell Tracker Green CMFDA (Invitrogen C7025), and then fixed with $4 \%$ paraformaldehyde. Slides were scanned using Zeiss 510 confocal microscopy (Carl Zeiss Microlmaging Inc.). The Cy3-A 342 relative intensity was analyzed with the NIH Image J software.

\section{Purification of apoE from immortalized astrocytes}

Lipidated apoE isoform particles were purified from culture media of human apoE3 or apoE4 overexpressing immortalized astrocytes using an affinity column, as we described previously [53]. Briefly, astrocytes were cultured in advanced DMEM (Invitrogen) with 10\% FBS. After 90-95\% confluency, cells were washed by PBS and further incubated in advanced DMEM with N-2 Supplement (Invitrogen) and $3 \mathrm{mM}$ 25-hydroxycholesterol (Sigma) for 3 days. Collected culture media were applied onto mouse monoclonal antibody against a human apoE (WU E-4) column. Lipidated apoE particles were eluted from the column with $3 \mathrm{M}$ sodium thiocyanate, concentrated using Apollo centrifugal quantitative concentrators (QMWL: $150 \mathrm{kDa}$, Orbital Biosciences), and dialyzed against PBS.

\section{Immunoblotting}

Cell samples transfected with scrambled siRNA or LRP1 siRNA were washed in cold PBS and lysed with RIPA buffer. Proteins were quantified with BCA protein assay kit (Pierce). An equal amount of protein sample was loaded for SDS-PAGE. We used the following primary antibodies: rabbit anti-mouse LRP1 (1: 20,000, Abcam, Cambridge, MA, USA), $\beta$-actin (1:10,000, Sigma), and $A \beta$ antibody (6E10, 1:1000, Covance). Images were scanned using ChemiDoc $^{\mathrm{Tm}}$ MP imager with LEDs and quantified using Image Lab ${ }^{\text {tw }}$ software (Bio-Rad, Hercules, CA, USA).

\section{Terminal deoxynucleotidyl transferase UTP nick end} labeling (TUNEL)

Paraformaldehyde-fixed, paraffin embedded brain tissue sections from $A P P^{S w / 0}$ mice were sectioned at a thickness of $10 \mu \mathrm{m}$. Immunofluorescent detection of pericytes (CD13-positive), $A \beta$ and endothelial-specific lectin fluorescence was conducted as described above. The DeadEnd Fluorometric TUNEL system (Promega) was then completed as described by the manufacturer.

\section{Statistical analysis}

All quantified data represent as mean \pm s.e.m. Student's $t$-test or one-way analysis of variance (ANOVA) followed by Bonferroni post-hoc test was used to determine statistically significant differences. A $P$ value $<0.05$ was considered statistically significant.

\section{Results}

$A \beta$ accumulation in pericytes from $A D$ patients and $\mathrm{APP}^{\mathrm{Sw} / 0}$ mice

Using 3-channel confocal microscopy, here we show that $\mathrm{A} \beta$ accumulates in $>30 \%$ of $\mathrm{CD} 13+$ and/or PDGFR $\beta+$ pericytes on lectin + brain endothelial capillary profiles $(<6 \mu \mathrm{m}$ in diameter) in brain cortical sections from $A D$ patients compared to barely detectable $A \beta$ accumulation in pericytes in age-matched controls (see demographic Additional file 1: Table S1; Fig. 1a-f). To confirm this observation, we immunostained cortical sections of 8.5-month-old $A P P^{S w / O}$ mice for human $A \beta$, at a disease stage when these mice begin depositing $A \beta$ [21]. We found that nearly $60 \%$ of $\mathrm{CD} 13+$ pericytes were positive for human $\mathrm{A} \beta$ (Fig. 1g-h). Collectively, these findings indicate that pericytes in $\mathrm{AD}$ and $A P P^{S w / 0}$ mouse brains both accumulate $\mathrm{A} \beta$. Additionally, we found that $A \beta$ also accumulates in brain endothelium of $\mathrm{AD}$ patients (Additional file 1: Figure S1A, B), and in lectin+ brain endothelial cells of 8.5-month-old $A P P^{S w / 0}$ mice (Additional file 1:Figure S1C).

\section{$A \beta$ accumulation is associated with pericyte cell death}

Cultured mouse pericytes [37] and human brain pericytes [54] die when treated with excess $A \beta$. To verify this result in $A P P^{S w / 0}$ mice in vivo, we performed quadruple TUNEL, $\mathrm{CD} 13$, lectin and human $\mathrm{A} \beta$ staining, which revealed a significant increase in TUNEL+ CD13+ pericytes in 8.5-month old, but not 3-month old, $A P P^{S w / 0}$ mice compared to 8.5-month old littermate controls (Fig. 1i-j), consistent with findings that 3-month old $A P P^{S w / O}$ mice show barely detectable $A \beta$ deposition in the brain compared to 8.5-month old mice, which begin depositing $A \beta$ at that stage [55].

\section{LRP1-dependent $A \beta$ uptake by pericytes on mouse brain slices}

To confirm $A \beta$ uptake by pericytes, we next conducted $A \beta$ uptake experiments on freshly isolated acute cortical slice 


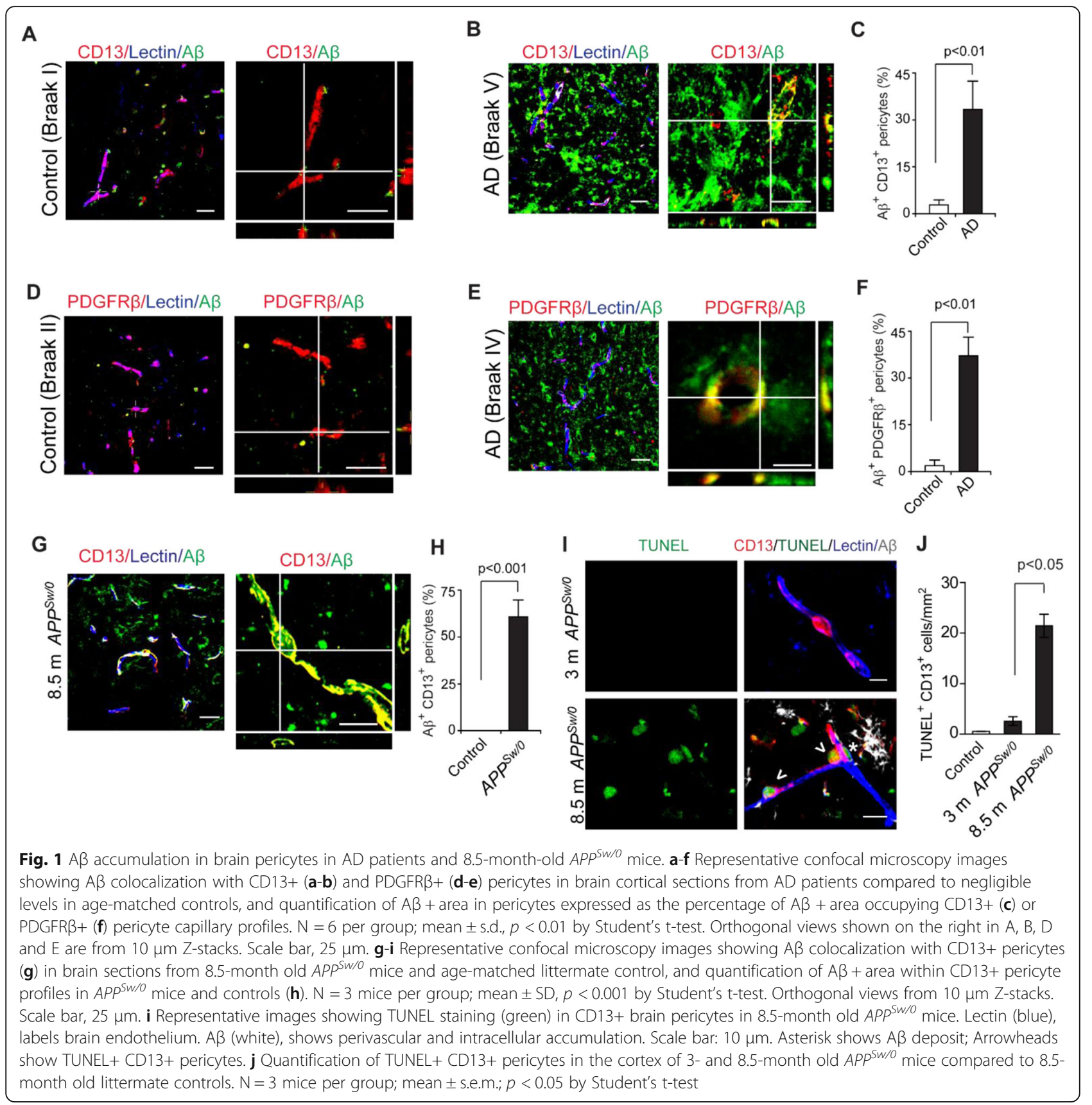

cultures, as previously reported [48]. In this experiment, the mouse brains slices were left to equilibrate in aCSF for $20 \mathrm{~min}$ at $37{ }^{\circ} \mathrm{C}$ with aeration, that was followed by incubation with Cy3-A $\beta 42(1 \mu \mathrm{M})$ for $30 \mathrm{~min}$ or $2 \mathrm{~h}$. Confocal microscopy was performed to analyze $A \beta$ internalization by pericytes (Fig. 2a). We found that uptake of Cy3-A $\beta 42$ by pericytes was rapid and time-dependent. Compared to $30 \mathrm{~min}$, at $2 \mathrm{~h}$ the amount of internalized Cy3-A 342 in $\mathrm{CD} 13+$ pericytes was further significantly increased (Fig. 2b-c). In these studies, A $\beta 42$ preparation contained a mixture of $A \beta 42$ monomers, dimers, trimers, tetramers, and small molecular weight oligomers
(Additional file 1: Figure S2). Both low (Fig. 2b) and high (Fig. 2d) magnification imaging analysis showed strong Cy3-A 342 fluorescence signal in CD13+ pericytes and/or PDGFR $\beta+$ pericytes (Additional file 1: Figure S3A-B). In addition to pericytes, Cy3-A $\beta 42$ uptake was observed by endothelial cells, astrocytes and microglia (Additional file 1: Figure S3C-E). The intracellular Cy3-A 342 levels in pericytes were significantly reduced in the presence of an anti-LRP1-specific antibody [22, 29] and the receptor associated protein (RAP) [52], an LRP1 antagonist which inhibits ligand binding to LRP1 (Fig. 2d), as shown by $17.1 \%$ and $21.7 \%$ of the $\mathrm{Cy} 3-\mathrm{A} \beta 42+$ area occupying CD13+ 


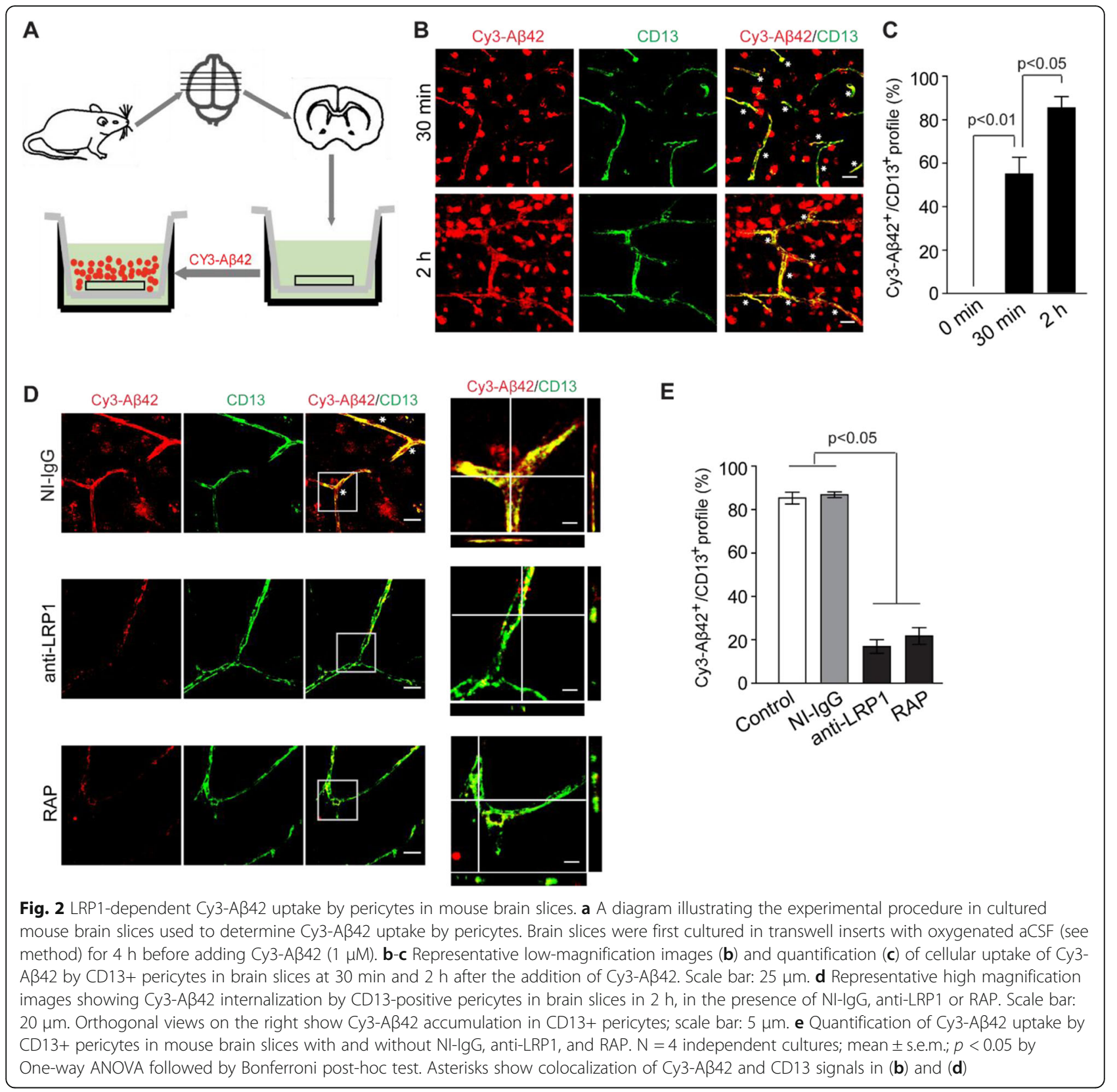

pericyte profiles, respectively, compared to $>80 \%$ in control slices treated with vehicle or non-immune immunoglobulin G (IgG) (Fig. 2d-e).

To further investigate the role of LRP1 in Cy3-A 342 uptake by pericytes, we generated conditional knockout mice with LRP1 deficiency in pericytes $\left(\operatorname{Lrp} 1^{l o x} /\right.$ lox; Cspg4-Cre) by crossing Lrp1 ${ }^{\text {lox/lox }}$ mice $[44,45]$ with Cspg4-Cre mice [46] (Fig. 3a). As expected, CD13+ pericytes on isolated brain microvessels from $\operatorname{Lrp}^{\text {lox/lox; }}$ Cspg4-Cre mice did not show a detectable LRP1 immunoreactivity in contrast to pericytes from control $\operatorname{Lrp1} 1^{l o x / l o x}$ mice, whereas LRP1 remained expressed in lectin+ endothelium in both $\operatorname{Lrp} 1^{\text {lox/lox }}$; Cspg4-Cre and
Lrp $1^{\text {lox/lox }}$ microvessels (Fig. 3b), confirming selective deletion of LRP1 from brain capillary pericytes. Both, Lrp1 $1^{\text {lox/lox }}$ and Lrp1 $1^{\text {lox/lox}}$; Cspg4-Cre mice had comparable CD13+ pericyte coverage (Additional file 1: Figure S4). Next, we studied Cy3-A 342 uptake on brain slices from these mice, as described above. Two hours after incubation, Cy3-A 342 uptake by $\mathrm{CD} 13+$ pericytes was reduced by $>80 \%$ in $\operatorname{Lrpl}^{\text {lox/lox}}$; Cspg4-Cre mice compared to control $\operatorname{Lrp} 1^{\text {lox/lox }}$ mice (Fig. 3c-e). As expected, A $\beta$ uptake by other cell types shown collectively as CD13cells was not affected in this Lrp1 conditional knockout model (Fig. 3f). In summary, these data demonstrate LRP1-depedent uptake of A $\beta 42$ species by pericytes. 
A

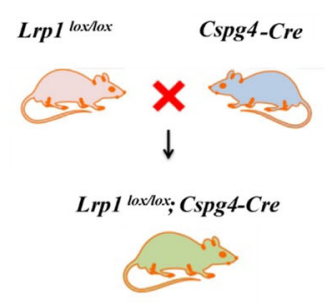

C
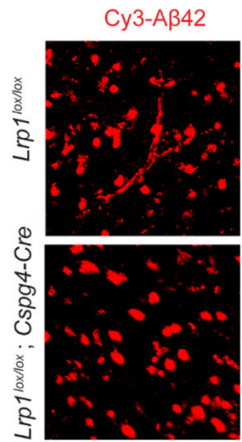

E

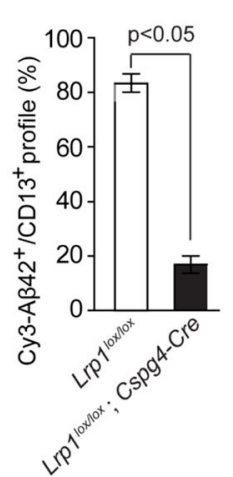

F
B

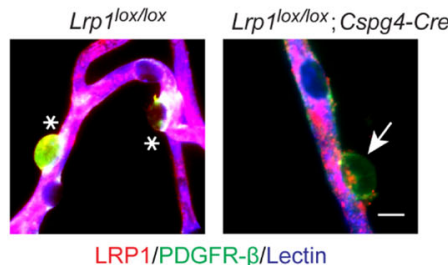

LRP1/PDGFR- $\beta / L e c t i n$

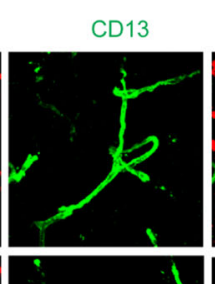

Cy3-A $42 / C D 13$

D
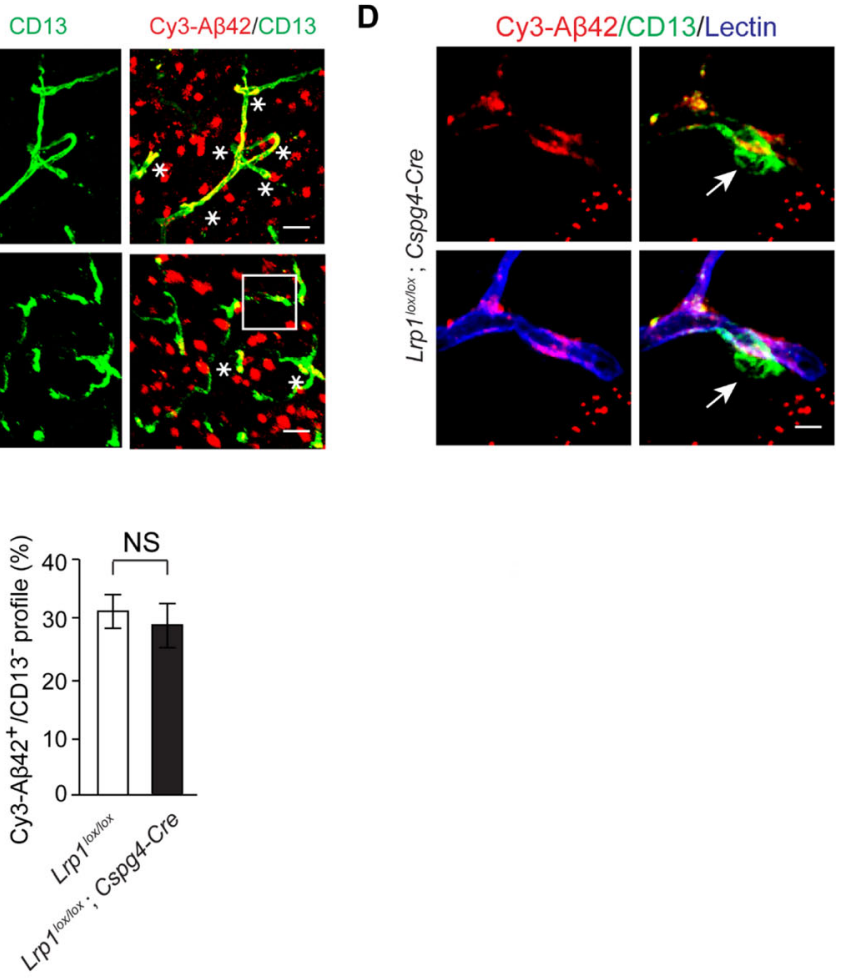

Fig. 3 LRP1 genetic deletion from pericytes inhibits Cy3-A 42 uptake by pericytes in mouse brain slices. a Diagram illustrating generation of Lrp 1 ${ }^{\text {lox/ox. }}$ Cspg4-Cre mice by crossing Lrp1 10x/lox mice with Cspg4-Cre mice. b Representative high magnification images showing LRP1 expression in CD13+ pericytes on isolated murine brain capillaries from control Lrp $1^{\text {lox/lox }}$ mice, but not Lrp $1^{\text {lox/lox; }}$ Cspg4-Cre mice with LRP1 deletion from pericytes. Asterisks show LRP1 immunostaining in CD13+ pericytes in control Lrp 10x/lox mice; arrow shows loss of LRP1 immunoreactivity in Lrp 1 lox/lox; Cspg4-Cre mice. Scale bar: $5 \mu \mathrm{m}$. c Representative images showing Cy3-AB42 internalization by CD13+ pericytes in brain slices from control Lrp ${ }^{\text {lox/lox }}$ mice, and a substantial loss of Cy3-A 42 uptake by pericytes in Lrp1 10x/lox; Cspg4-Cre mice. Asterisks show colocalization between Cy3-A 42 and CD13 signals. Scale bar: $25 \mu \mathrm{m}$. d High magnification images showing greatly reduced Cy3-Aß42 internalization by a CD13+ pericyte on brain slices from Lrp 1/ox/lox; Cspg4Cre mice, in contrast to $A \beta$ uptake by lectin-positive endothelial cells. Arrow points to pericyte lacking Cy3-Aß42 signal. Scale bar: $5 \mu$ m. e, $\mathbf{f}$ Quantification of Cy3-A 42 cellular uptake by CD13+ pericytes (e) compared to all other CD13- (negative) brain cells (f) in brain slices from control Lrp1 lox/lox and Lrp1 10x/lox; Cspg4-Cre mice. N = 3 mice per group; mean \pm s.e.m.; NS, not significant, $p<0.05$ by Student's t-test

LRP1/apoE-dependent clearance of aggregated Cy3-A 342 by mouse brain capillary pericytes

To determine whether pericytes can clear aggregated $A \beta$, we used a slightly modified $A \beta$ clearance model with pericytes seeded on multi-spot glass slides pre-coated with aggregated $\mathrm{Cy} 3-\mathrm{A} \beta 42$, as we reported previously in studies with primary VSMCs [29] (Fig. 4a). Five days after culture, the majority of A $\beta 42$ aggregates (>70\%) were removed from the multi-spot surface by pericytes in the presence of vehicle, control non-immune IgG or scrambled short interfering si.Control (Fig. 4b-c), when compared to cell-free control (Fig. 4a). In contrast, only $22.8 \%, 27.3 \%$ and $12.9 \%$ of Cy3-A 342 was cleared in the presence of anti-LRP1 [22, 29], RAP [52] and si.Lrp1 (Fig. 4c), respectively. In silencing experiment, si.Lrp1 efficiently downregulated LRP1 in pericytes by $~ 90 \%$ when compared to si.Control (Additional file 1: Figure $\mathrm{S} 5 \mathrm{~A})$. We also found a time-dependent increase in cell death of pericytes cultured on $\mathrm{A} \beta$ pre-coated slides, from $8.2 \%$ at 3 DIV to $18.7 \%$ at 5 DIV, whereas inhibiting LRP1 by an anti-LRP1 antibody or LRP1 silencing (si.Lrp1), not only significantly reduced $\mathrm{A} \beta$ uptake, but 


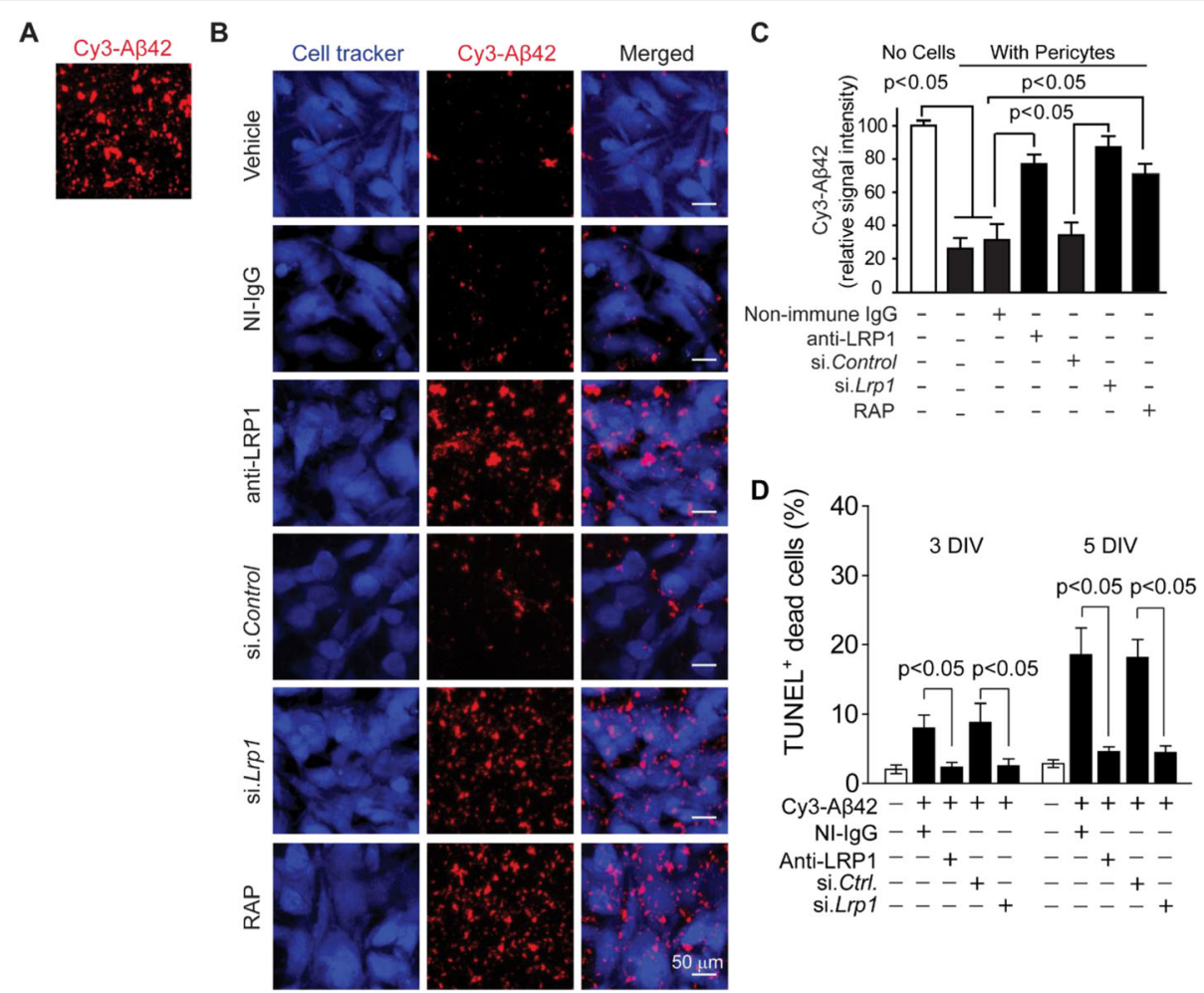

Fig. 4 LRP1 mediates clearance of aggregated Cy3-A 42 by mouse pericytes. a-b Multiphoton/confocal laser scanning microscopy of multi-spot glass slides coated with Cy3-A 42 without cells (a), and with primary mouse brain pericytes cultured for 5 days in the presence of NI-lgG or anti-LRP1, after si.Lrp1 silencing compared to scrambled si.Control, and with RAP or vehicle (b). Scale bar, $50 \mu \mathrm{m}$. c Quantification of Cy3-Aß42 relative signal intensity on multi-spot slides after 5 days without cells (open bar on the left) and with pericytes in the presence of vehicle (control), NI-lgG and anti-LRP1, after silencing with scrambled si.Control or si.Lrp1, and in the presence of RAP. N = 4 independent cultures (biological replicates, see Methods); mean \pm s.e.m.; $\mathrm{p}<0.05$ by One-way ANOVA followed by Bonferroni post-hoc test. $\mathbf{d}$ Quantification of TUNEL+ pericyte cell death at 3 and 7 days after seeding on multi-spot glass slides coated with Cy3-Aß42 in the presence and absence of NI-lgG and anti-LRP1, and after si.Lrp1 silencing or si.Ctrl as in (b). N= 3 independent cultures per group; mean \pm s.e.m.; $p<0.05$ by One-way ANOVA followed by Bonferroni post-hoc test

also diminished pericyte cell death by approximately 3 and 4-fold at 3 and 5 DIV, respectively (Fig. 4d), suggesting that reducing $A \beta$ uptake decreases $A \beta$ toxicity consistent with previous studies with soluble $A \beta$ [37] or Dutch A $\beta$ peptides [54].

To check whether apoE is required for LRP1-mediated clearance of $A \beta$ aggregates, we studied clearance by pericytes in the presence of an apoE specific blocking antibody compared to non-immune IgG, and after silencing mouse apoE (si.Apoe) compared to scrambled si.Control (Additional file 1: Figure S5B; Fig. 5a). After 5 days, we found substantially reduced $A \beta$ clearance with either pharmacologic or genetic inhibition of murine apoE in pericytes as illustrated by representative confocal microscopy images (Fig. 5a), quantification of time-dependent Cy3-A $\beta 42$ clearance by mouse pericytes cultured for 1,3 and 5 days after silencing mouse endogenous apoE (si.Apoe) compared to si.Control (Fig. 5b), and quantification analysis of Cy3-A 342 relative signal intensity on multi-spot slides after 5 days of culture with pericytes under different experimental conditions (Fig. 5c). These data suggest that pericyte-derived apoE is required for clearance of $A \beta$ aggregates by cultured pericytes, which we show is mediated by LRP1, an apoE receptor (see Fig. 2d-e; Fig. 3c-e and Fig. 4b-c). Besides the self-autonomous effect of apoE in regulating clearance of $\mathrm{A} \beta$ aggregates by pericytes (Fig. 5a-c), to mimic in vivo situation we next studied the non-autonomous effects of astrocyte-derived apoE by adding lipidated human apoE3 or apoE4 particles prepared from immortalized astrocytes, as previously described [53]. Previous work has shown that astrocyte-derived apoE provides a major source of apoE in the brain in vivo and signals pericytes via LRP1, but not LRP2, very low density lipoprotein receptor (VLDLR), low density lipoprotein receptor (LDLR) or apoER2 [49]. The effects of apoE3 and apoE4 on $\mathrm{A} \beta$ clearance by pericytes was studied after silencing mouse apoE (si.Apoe). ApoE3, but not apoE4, almost completely reversed $\mathrm{A} \beta$ clearance by pericytes with inhibited mouse apoE (Fig. 5a-c), suggesting that astrocyte-derived apoE exerts a non-autonomous isoform-specific effect on $A \beta$ clearance by pericytes. To additionally confirm that apoE3 effect on pericytes requires LRP1 as previously shown [49], we performed the same 


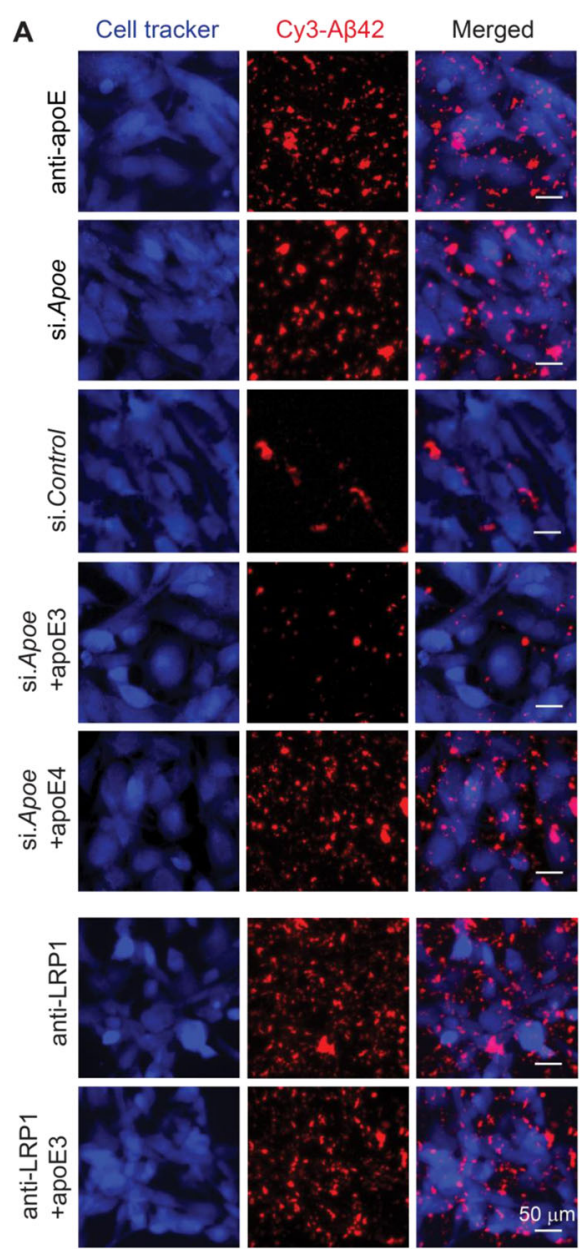

B

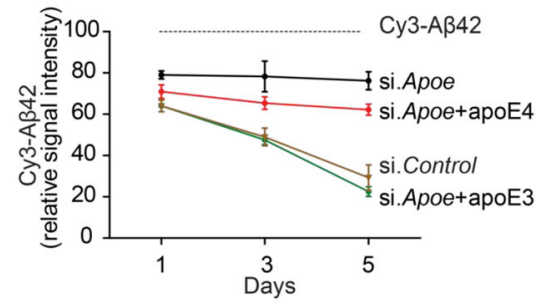

C

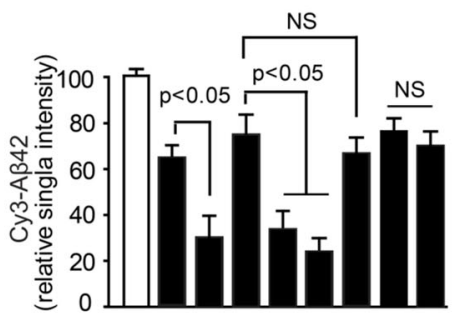

anti-apoE - + - - - - Non-immune $\lg \mathrm{G}-\quad+-{ }_{-}-{ }_{-}$

si.Apoe - - - + + + -

si.Control - - - + - - -

apoE3 - - - - - + - +

apoE4 - - - - + -

anti-LRP1 - $-\quad-\quad-++$

Fig. 5 Apolipoprotein E-dependent and isoform-specific effect on LRP1-mediated clearance of aggregated Cy3-Aß42 by mouse pericytes. a Multiphoton/confocal laser scanning microscopy of multi-spot glass slides coated with Cy3-Aß42 with primary mouse brain pericytes cultured for 5 days in the presence of mouse apoE-specific blocking antibody (anti-apoE), after silencing mouse endogenous apoE (si.Apoe) compared to scrambled si.Control, and after silencing mouse apoE (si.Apoe) in the presence of astrocyte-derived lipidated human apoE3 or apoE4 (40 nM) with and without anti-LRP1 antibody. Scale bar, $50 \mu \mathrm{m}$. b Time-dependent Cy3-A 342 clearance by mouse pericytes cultured for 1, 3 and 5 days after silencing mouse endogenous apoE (si.Apoe) compared to si.Control, and in the presence of human apoE3 or apoE4. Dashed line indicates Cy3A 42 signal in the absence of cells (control without cells). c Quantification analysis of Cy3-A 342 relative signal intensity on multi-spot slides after 5 days of culture with pericytes under different experimental conditions as indicated. Gray bar shows Cy3-Aß42 signal in the absence of cells (control without cells). $\mathrm{N}=3$ independent cultures; mean \pm s.e.m.; $\mathrm{p}<0.05$ by one-way ANOVA followed by Bonferroni post-hoc test

experiment in the presence of an anti-LRP1 antibody. As expected, this experiment showed that anti-LRP1 inhibits apoE3's ability to reverse the $A \beta$ clearing capability of mouse pericytes with silenced mouse apoE (si.Apoe) (Fig. 5a, c).

\section{Discussion}

Our data show that BBB-associated pericytes accumulate an abundance of $\mathrm{A} \beta$ on brain capillaries in $\mathrm{AD}$ patients and $A P P^{S w / 0}$ mice. We also show that pericytes play a major role in clearance of different $A \beta 42$ species including a mixture of monomers and small molecular weight oligomers, which is mediated via LRP1, similar as previously shown for $A \beta 40$ [37]. This has been demonstrated by pharmacologic inhibition of LRP1 by an anti-LRP1 antibody [22, 29] and RAP [52], genetic Lrp1 knockdown with short interfering RNA (si.Lrp1) and deletion of LRP1 from pericytes in $\operatorname{Lrp}^{\text {lox/lox}}$; Cspg4-Cre mice compared to $L r p^{\text {lox/lox }}$ controls. Moreover, we show that pericytes efficiently clear A $\beta 42$ aggregates by an LRP1/apoE isoform-specific mechanism. This has been demonstrated by silencing mouse Apoe (si.Apoe) in pericytes in the absence and presence of human astrocyte-derived lipidated apoE3 or apoE4, which revealed that apoE3, but not apoE4, mediates LRP1-dependent clearance of Cy3-A 342 aggregates. Overall, these data point to $A \beta$ clearance on pericytes as a possible contributory factor in the pathogenesis of $A D$ and accumulation of $A \beta$ in the brain and around brain capillaries causing capillary CAA as seen in 
AD [8]. The data also suggest that LRP1/apoE interaction on pericytes should be explored further as a potential therapeutic approach for controlling $\mathrm{A} \beta$ clearance in $\mathrm{AD}$.

Accumulation of $\mathrm{A} \beta$ in pericytes in $\mathrm{AD}$ and $A P P$ mouse brain capillaries likely reflects $A \beta$ overload that exceeds pericytes clearance capability resulting in intracellular trapping of $A \beta$. This in turn may set a stage for the formation of amyloid deposits around brain capillaries and within the basement membrane between pericytes and endothelial cells, as shown in AD [7, 8] and APP models [21]. Consistent with these findings we also observed accumulation of $\mathrm{A} \beta$ in the brain endothelium in both $\mathrm{AD}$ and $A P P^{S w / 0}$ mice likely reflecting excess $A \beta$ that has not been cleared via transport across the BBB [27]. Collectively, these data suggest that not only previously shown faulty clearance of $A \beta$ on VSMCs contributes to CAA and A $\beta$ pathology $[29,30]$, but also impaired clearance on pericytes may contribute to development of capillary CAA $[8,21]$ and retention of $\mathrm{A} \beta$ in the brain. This might be particularly important at disease stages when other clearance mechanisms including $A \beta$ drainage by the perivascular route and/or the meningeal lymphatics become deficient, as recently shown in $A P P$ mouse models [16, 17].

Pericyte degeneration and loss have been reported in AD patients [47, 56-59] and APP mice [37, 60]. Consistent with previous findings demonstrating that excess $A \beta$ in pericytes can trigger cell death in human [54] and mouse [37] pericytes, we also found that pericytes in $A P P^{S w / 0}$ mice die at the time of $\mathrm{A} \beta$ deposition in the brain and its accumulation in pericytes. Pericyte cell death, in turn, can exacerbate progression of AD pathology, as shown in $A P P^{S w / 0} ; P d g f r b^{+/-}$mice with accelerated pericyte loss [37]. Similar as shown in human pericytes [54], we also found that LRP1 mediates both $\mathrm{A} \beta$ internalization and cell death of mouse pericytes, as illustrated by diminished $A \beta$ uptake and reduced cell death in the presence of LRP1 inhibition by either an anti-LRP1 antibody and/or Lrp1 silencing. Consistent with the present findings, previous studies by Verbeek and colleagues [54,61-63] suggested that $A \beta$ effects on pericytes are modulated by apoE isoforms. In brief, they showed that human pericytes from apoE4 carriers compared to apoE3 carriers secrete less apoE in the culture media resulting in increased accumulation of Dutch $A \beta$ peptide on the cell surface and greater rate of cell death induced by $\mathrm{A} \beta$ [63].

Interestingly, loss of pericytes in human $\mathrm{AD}$ is significantly higher in apoE4 carriers compared to apoE3 carriers, which is associated with greater degree of $\mathrm{BBB}$ breakdown [56, 64], and increased risk for CAA, as shown both in human apoE4 compared to apoE3 carriers [65-69], and APP mouse models on apoE4 compared to apoE3 background [66, 70]. These findings are consistent with the present data showing that human astrocyte-derived apoE4, in contrast to apoE3, cannot reverse LRP-1-mediated A $\beta$ clearance by mouse pericytes with silenced mouse endogenous apoE, and previous findings demonstrating that apoE4 compared to apoE3 poorly binds to LRP1, which leads from on one hand to $\mathrm{BBB}$ breakdown by activating BBB-degrading cyclophilin-A-matrix metallopropteinase- 9 pathway in pericytes [49], and from the other, diminished clearance of $A \beta$ across the BBB [39].

Finally, the present findings showing that pericytes actively contribute to $\mathrm{A} \beta$ removal at the $\mathrm{BBB}$ via LRP1-mediated apoE isoform-dependent clearance on brain capillaries should encourage future studies directed at exploring possible therapeutic potential of this pathway to control CAA and A $\beta$ pathology in AD. For example, pharmacologic or genetic strategies that can increase activity of LRP1/apoE clearance system in pericytes and at the $\mathrm{BBB}$ might diminish $\mathrm{CAA}$ and $\mathrm{A} \beta$ accumulation in apoE3 carriers, but may not work as well in apoE4 carriers. On the other hand, recent cell therapy studies have shown that mouse mesodermal pericytes can improve cerebral blood flow and reduce A $\beta$ pathology when injected into the brain of APP mice [38]. Based on the present findings, this therapeutic effect likely depends on mouse endogenous apoE. When translating this approach to humans, based on the present findings one can envisage using iPSC-derived pericytes from apoE3 carriers as a straight $\mathrm{A} \beta$ lowering cell clearance therapy, whereas in case of apoE4 carriers, CRISPER/Cas9 approach could be used to generate apoE3-secreting iPSC-derived pericytes with enhanced A $\beta$ clearance properties.

\section{Conclusions}

In conclusion, our findings show that BBB-associated pericytes clear $A \beta$ aggregates via an LRP1-dependent apoE isoform-specific mechanism with apoE4 disrupting $\mathrm{A} \beta$ clearance compared to apoE3. Overall, the present data support that the LRP1/apoE pathway in pericytes has a potential to be explored as a therapeutic target for controlling $\mathrm{A} \beta$ clearance and levels in $\mathrm{AD}$.

\section{Additional file}

$$
\begin{aligned}
& \text { Additional file 1: Table S1. Demographic and clinical features of human } \\
& \text { subjects used in this study. Figure S1. A } \beta \text { deposition in microvessels in AD } \\
& \text { patients and } A P P^{S w / 0} \text { mice. Figure S2. Biochemical analysis of } A \beta 42 \\
& \text { aggregates. Figure S3. Cy3-A } 42 \text { cellular uptake in wild type mouse brain } \\
& \text { slices within } 30 \text { min. Figure S4. Pericyte coverages in } L r p 1^{\text {lox/lox }} \text { and } L r p 1^{\text {lox/ }} \\
& \text { lox; Cspg4-Cre mice. Figure S5. LRP1 and apoE suppression with siRNA. } \\
& \text { (DOCX } 1454 \mathrm{~kb} \text { ) }
\end{aligned}
$$

\section{Abbreviations}

aCSF: Artificial cerebrospinal fluid; AD: Alzheimer's disease; apoE: Apolipoprotein $E_{;}$APP: A $\beta$-precursor protein; $A \beta$ : Amyloid- $\beta$; 
BBB: Blood-brain barrier; CAA: Cerebral amyloid angiopathy; CD13: Cluster of differentiation 13; CERAD: Consortium to establish a registry for Alzheimer's disease; Cspg4: Chondroitin sulfate proteoglycan 4; Cy3: Cyanine 3; FBS: Fetal bovine serum; ISF: Interstitial fluid; LRP1: Low density lipoprotein receptor related protein 1; PFA: Paraformaldehyde; PICALM: Phosphatidylinositol binding clathrin assembly protein; RAP: Receptor-associated protein; TUNEL: Terminal deoxynucleotidyl transferase UTP nick end labeling; VSMCs: Vascular smooth muscle cells

\section{Acknowledgements}

We thank Dr. Le Ma for technical assistance on experiments using mouse brain slices.

\section{Funding}

The was supported by the National Institutes of Health grants R01NS034467, R01AG023084, R01AG039452, and the Foundation Leducq Transatlantic Network of Excellence for the Study of Perivascular Spaces in Small Vessel Disease reference no. 16 CVD 05 to BVZ, and the Cure for Alzheimer's Fund to BVZ and ZZ

\section{Availability of data and materials}

The data that support the findings of this study are available from the corresponding author upon reasonable request.

\section{Authors' contributions}

QM and ZZ designed and performed experiments and analyzed data and contributed to writing the manuscript. APS, YW, MW and NCO performed experiments. PBV, JH and DMH provided key reagent or animal model, and contributed to writing the manuscript. BVZ designed all experiments, analyzed data and wrote the paper. All authors read and approved the final manuscript.

\section{Ethics approval and consent to participate}

The animal experiments were approved by the Institutional Animal Care and Use Committee at the University of Southern California with National Institutes of Health guidelines.

\section{Consent for publication}

Not applicable.

\section{Competing interests}

$\mathrm{DMH}$ is an inventor on a patent filed by Washington University on the topic of anti-apoE antibodies that was licensed by Denali. DMH co-founded and is on the scientific advisory board of $\mathrm{C}_{2} \mathrm{~N}$ Diagnostics. DMH consults for Genentech, AbbVie, Eli Lilly, Proclara, and Denali. Washington University receives research grants to the lab of DMH from C2N Diagnostics, AbbVie, and Denali. PBV, is a full-time employee of C2N Diagnostics, receiving stock and/or stock options.

\section{Publisher's Note}

Springer Nature remains neutral with regard to jurisdictional claims in published maps and institutional affiliations.

\section{Author details}

${ }^{1}$ Center for Neurodegeneration and Regeneration, Zilkha Neurogenetic Institute and Department of Physiology and Neuroscience, Keck School of Medicine, University of Southern California, Los Angeles, California 90033, USA. ² Lawrence D. Longo, MD Center for Neonatal Biology, Division of Pharmacology, Department of Basic Sciences, Loma Linda University School of Medicine, Loma Linda, CA 92350, USA. ${ }^{3}$ C2N Diagnostics, LLC, Saint Louis, MO 63110, USA. ${ }^{4}$ Department of Molecular Genetics, University of Texas Southwestern Medical Center, Dallas, TX, USA. ${ }^{5}$ Department of Neuroscience, University of Texas Southwestern Medical Center, Dallas, TX, USA. 'Department of Neurology and Neurotherapeutics and Center for Translational Neurodegeneration Research, University of Texas Southwestern Medical Center, Dallas, TX, USA. 'DDepartment of Neurology, Hope Center for Neurological Disorders, Knight Alzheimer's Disease Research Center, Washington University School of Medicine, Saint Louis, MO 63110, USA.
Received: 30 August 2018 Accepted: 1 October 2018 Published online: 19 October 2018

\section{References}

1. Sweeney MD, Sagare AP, Zlokovic BV. Blood-brain barrier breakdown in Alzheimer disease and other neurodegenerative disorders. Nat Rev Neurol. 2018:14:133-50.

2. Jack CR Jr, Bennett DA, Blennow K, Carrillo MC, Dunn B, Haeberlein SB, Holtzman DM, Jagust W, Jessen F, Karlawish J, et al. NIA-AA research framework: toward a biological definition of Alzheimer's disease. Alzheimers Dement. 2018;14:535-62.

3. Hardy J, Selkoe DJ. The amyloid hypothesis of Alzheimer's disease: progress and problems on the road to therapeutics. Science. 2002;297:353-6.

4. Selkoe DJ, Hardy J. The amyloid hypothesis of Alzheimer's disease at 25 years. EMBO Mol Med. 2016;8:595-608.

5. Choi SH, Kim YH, Hebisch M, Sliwinski C, Lee S, D'Avanzo C, Chen H, Hooli B, Asselin C, Muffat J, et al. A three-dimensional human neural cell culture model of Alzheimer's disease. Nature. 2014:515:274-8.

6. Zlokovic BV. Cerebrovascular effects of apolipoprotein E: implications for Alzheimer disease. JAMA Neurol. 2013:70:440-4

7. Snyder HM, Corriveau RA, Craft S, Faber JE, Greenberg SM, Knopman D, Lamb BT, Montine TJ, Nedergaard M, Schaffer CB, et al. Vascular contributions to cognitive impairment and dementia including Alzheimer's disease. Alzheimers Dement. 2015:11:710-7.

8. Hecht M, Kramer LM, von Arnim CAF, Otto M, Thal DR. Capillary cerebral amyloid angiopathy in Alzheimer's disease: association with allocortical/ hippocampal microinfarcts and cognitive decline. Acta Neuropathol. 2018; 135:681-94.

9. Wermer MJH, Greenberg SM. The growing clinical spectrum of cerebral amyloid angiopathy. Curr Opin Neurol. 2018;31:28-35.

10. Zhao Z, Nelson AR, Betsholtz C, Zlokovic BV. Establishment and dysfunction of the blood-brain barrier. Cell. 2015;163:1064-78.

11. Leissring MA. Abeta-degrading proteases: therapeutic potential in Alzheimer disease. CNS Drugs. 2016;30:667-75

12. Tarasoff-Conway JM, Carare RO, Osorio RS, Glodzik L, Butler T, Fieremans E, Axel L, Rusinek H, Nicholson C, Zlokovic BV, et al. Clearance systems in the brain-implications for Alzheimer disease. Nat Rev Neurol. 2015;11:457-70.

13. Bakker EN, Bacskai BJ, Arbel-Ornath M, Aldea R, Bedussi B, Morris AW, Weller $\mathrm{RO}$, Carare RO. Lymphatic clearance of the brain: perivascular, paravascular and significance for neurodegenerative diseases. Cell Mol Neurobiol. 2016; 36:181-94.

14. Engelhardt B, Carare RO, Bechmann I, Flugel A, Laman JD, Weller RO. Vascular, glial, and lymphatic immune gateways of the central nervous system. Acta Neuropathol. 2016;132:317-38.

15. Engelhardt B. Cluster: barriers of the central nervous system. Acta Neuropathol. 2018;135:307-10.

16. Sweeney MD, Zlokovic BV. A lymphatic waste-disposal system implicated in Alzheimer's disease Nature 2018:560:172-4

17. Da Mesquita S, Louveau A, Vaccari A, Smirnov I, Cornelison RC, Kingsmore KM, Contarino C, Onengut-Gumuscu S, Farber E, Raper D, et al. Functional aspects of meningeal lymphatics in ageing and Alzheimer's disease. Nature. 2018:560:185-91.

18. Zlokovic BV. Neurovascular pathways to neurodegeneration in Alzheimer's disease and other disorders. Nat Rev Neurosci. 2011:12:723-38.

19. Mawuenyega KG, Sigurdson W, Ovod V, Munsell L, Kasten T, Morris JC, Yarasheski KE, Bateman RJ. Decreased clearance of CNS beta-amyloid in Alzheimer's disease. Science. 2010;330:1774.

20. Roberts KF, Elbert DL, Kasten TP, Patterson BW, Sigurdson WC, Connors RE, Ovod V, Munsell LY, Mawuenyega KG, Miller-Thomas MM, et al. Amyloidbeta efflux from the central nervous system into the plasma. Ann Neurol. 2014;76:837-44

21. Montagne A, Zhao Z, Zlokovic BV. Alzheimer's disease: a matter of bloodbrain barrier dysfunction? J Exp Med. 2017;214:3151-69.

22. Bell RD, Sagare AP, Friedman AE, Bedi GS, Holtzman DM, Deane R, Zlokovic BV. Transport pathways for clearance of human Alzheimer's amyloid betapeptide and apolipoproteins $E$ and $J$ in the mouse central nervous system. $J$ Cereb Blood Flow Metab. 2007:27:909-18.

23. Holtzman DM, Herz J, Bu G. Apolipoprotein E and apolipoprotein E receptors: normal biology and roles in Alzheimer disease. Cold Spring Harb Perspect Med. 2012;2:a006312. 
24. Kanekiyo T, Xu H, Bu G. ApoE and Abeta in Alzheimer's disease: accidental encounters or partners? Neuron. 2014;81:740-54.

25. Shibata M, Yamada S, Kumar SR, Calero M, Bading J, Frangione B, Holtzman DM, Miller CA, Strickland DK, Ghiso J, Zlokovic BV. Clearance of Alzheimer's amyloid-ss(1-40) peptide from brain by LDL receptor-related protein-1 at the blood-brain barrier. J Clin Invest. 2000;106:1489-99.

26. Deane R, Wu Z, Sagare A, Davis J, Du Yan S, Hamm K, Xu F, Parisi M, LaRue $\mathrm{B}, \mathrm{Hu} \mathrm{HW}$, et al. LRP/amyloid beta-peptide interaction mediates differential brain efflux of Abeta isoforms. Neuron. 2004:43:333-44.

27. Zhao Z, Sagare AP, Ma Q, Halliday MR, Kong P, Kisler K, Winkler EA, Ramanathan A, Kanekiyo T, Bu G, et al. Central role for PICALM in amyloid-beta blood-brain barrier transcytosis and clearance. Nat Neurosci. 2015;18:978-87.

28. Storck SE, Meister S, Nahrath J, Meissner JN, Schubert N, Di Spiezio A, Baches S, Vandenbroucke RE, Bouter Y, Prikulis I, et al. Endothelial LRP1 transports amyloid-beta(1-42) across the blood-brain barrier. J Clin Invest. 2016;126:123-36.

29. Bell RD, Deane R, Chow N, Long X, Sagare A, Singh I, Streb JW, Guo H, Rubio A, Van Nostrand W, et al. SRF and myocardin regulate LRP-mediated amyloid-beta clearance in brain vascular cells. Nat Cell Biol. 2009:11:143-53.

30. Kanekiyo T, Liu CC, Shinohara M, Li J, Bu G. LRP1 in brain vascular smooth muscle cells mediates local clearance of Alzheimer's amyloid-beta. J Neurosci. 2012;32:16458-65.

31. Koistinaho M, Lin S, Wu X, Esterman M, Koger D, Hanson J, Higgs R, Liu F, Malkani S, Bales KR, Paul SM. Apolipoprotein E promotes astrocyte colocalization and degradation of deposited amyloid-beta peptides. Nat Med. 2004;10:719-26.

32. Sweeney MD, Ayyadurai S, Zlokovic BV. Pericytes of the neurovascular unit: key functions and signaling pathways. Nat Neurosci. 2016;19:771-83.

33. Armulik A, Genove G, Mae M, Nisancioglu MH, Wallgard E, Niaudet C, He L, Norlin J, Lindblom P, Strittmatter K, et al. Pericytes regulate the blood-brain barrier. Nature. 2010;468:557-61.

34. Bell RD, Winkler EA, Sagare AP, Singh I, LaRue B, Deane R, Zlokovic BV. Pericytes control key neurovascular functions and neuronal phenotype in the adult brain and during brain aging. Neuron. 2010;68:409-27.

35. Kisler K, Nelson AR, Rege SV, Ramanathan A, Wang Y, Ahuja A, Lazic D, Tsai PS, Zhao Z, Zhou Y, et al. Pericyte degeneration leads to neurovascular uncoupling and limits oxygen supply to brain. Nat Neurosci. 2017;20:406-16.

36. Montagne A, Nikolakopoulou AM, Zhao Z, Sagare AP, Si G, Lazic D, Barnes SR, Daianu M, Ramanathan A, Go A, et al. Pericyte degeneration causes white matter dysfunction in the mouse central nervous system. Nat Med. 2018;24:326-37.

37. Sagare AP, Bell RD, Zhao Z, Ma Q, Winkler EA, Ramanathan A, Zlokovic BV. Pericyte loss influences Alzheimer-like neurodegeneration in mice. Nat Commun. 2013:4:2932

38. Tachibana M, Yamazaki Y, Liu CC, Bu G, Kanekiyo T. Pericyte implantation in the brain enhances cerebral blood flow and reduces amyloid-beta pathology in amyloid model mice. Exp Neurol. 2018;300:13-21.

39. Deane R, Sagare A, Hamm K, Parisi M, Lane S, Finn MB, Holtzman DM, Zlokovic BV. apoE isoform-specific disruption of amyloid beta peptide clearance from mouse brain. J Clin Invest. 2008;118:4002-13.

40. Verghese PB, Castellano JM, Holtzman DM. Apolipoprotein E in Alzheimer's disease and other neurological disorders. Lancet Neurol. 2011;10:241-52.

41. Liao F, Yoon H, Kim J. Apolipoprotein E metabolism and functions in brain and its role in Alzheimer's disease. Curr Opin Lipidol. 2017:28:60-7.

42. Liu CC, Liu CC, Kanekiyo T, Xu H, Bu G. Apolipoprotein E and Alzheimer disease: risk, mechanisms and therapy. Nat Rev Neurol. 2013;9:106-18.

43. Hsiao K, Chapman P, Nilsen S, Eckman C, Harigaya Y, Younkin S, Yang F, Cole G. Correlative memory deficits, Abeta elevation, and amyloid plaques in transgenic mice. Science. 1996;274:99-102.

44. Boucher P, Gotthardt M, Li WP, Anderson RG, Herz J. LRP: role in vascular wall integrity and protection from atherosclerosis. Science. 2003;300:329-32.

45. Rohlmann A, Gotthardt M, Hammer RE, Herz J. Inducible inactivation of hepatic LRP gene by cre-mediated recombination confirms role of LRP in clearance of chylomicron remnants. J Clin Invest. 1998;101:689-95.

46. Zhu X, Bergles DE, Nishiyama A. NG2 cells generate both oligodendrocytes and gray matter astrocytes. Development. 2008;135:145-57.

47. Sengillo JD, Winkler EA, Walker CT, Sullivan JS, Johnson M, Zlokovic BV Deficiency in mural vascular cells coincides with blood-brain barrier disruption in Alzheimer's disease. Brain Pathol. 2013;23:303-10.

48. Kandimalla KK, Scott OG, Fulzele S, Davidson MW, Poduslo JF. Mechanism of neuronal versus endothelial cell uptake of Alzheimer's disease amyloid beta protein. PLoS One. 2009;4:e4627.
49. Bell RD, Winkler EA, Singh I, Sagare AP, Deane R, Wu Z, Holtzman DM, Betsholtz C, Armulik A, Sallstrom J, et al. Apolipoprotein E controls cerebrovascular integrity via cyclophilin a. Nature. 2012;485:512-6.

50. Wu Z, Hofman FM, Zlokovic BV. A simple method for isolation and characterization of mouse brain microvascular endothelial cells. J Neurosci Methods. 2003;130:53-63.

51. Wyss-Coray T, Loike JD, Brionne TC, Lu E, Anankov R, Yan F, Silverstein SC, Husemann J. Adult mouse astrocytes degrade amyloid-beta in vitro and in situ. Nat Med. 2003;9:453-7.

52. Herz J, Goldstein JL, Strickland DK, Ho YK, Brown MS. 39-kDa protein modulates binding of ligands to low density lipoprotein receptor-related protein/alpha 2-macroglobulin receptor. J Biol Chem. 1991;266:21232-8.

53. Morikawa M, Fryer JD, Sullivan PM, Christopher EA, Wahrle SE, DeMattos RB, O'Dell MA, Fagan AM, Lashuel HA, Walz T, et al. Production and characterization of astrocyte-derived human apolipoprotein E isoforms from immortalized astrocytes and their interactions with amyloid-beta. Neurobiol Dis. 2005;19:66-76.

54. Wilhelmus MM, Otte-Holler I, van Triel JJ, Veerhuis R, Maat-Schieman ML, Bu G, de Waal RM, Verbeek MM. Lipoprotein receptor-related protein-1 mediates amyloid-beta-mediated cell death of cerebrovascular cells. Am J Pathol. 2007:171:1989-99.

55. Webster Cl, Burrell M, Olsson LL, Fowler SB, Digby S, Sandercock A, Snijder A, Tebbe J, Haupts U, Grudzinska J, et al. Engineering neprilysin activity and specificity to create a novel therapeutic for Alzheimer's disease. PLoS One 2014;9:e104001.

56. Halliday MR, Rege SV, Ma Q, Zhao Z, Miller CA, Winkler EA, Zlokovic BV. Accelerated pericyte degeneration and blood-brain barrier breakdown in apolipoprotein E4 carriers with Alzheimer's disease. J Cereb Blood Flow Metab. 2016:36:216-27.

57. Farkas $E$, Luiten PG. Cerebral microvascular pathology in aging and Alzheimer's disease. Prog Neurobiol. 2001;64:575-611.

58. Baloyannis SJ, Baloyannis IS. The vascular factor in Alzheimer's disease: a study in Golgi technique and electron microscopy. J Neurol Sci. 2012;322:117-21.

59. Miners JS, Schulz I, Love S. Differing associations between Abeta accumulation, hypoperfusion, blood-brain barrier dysfunction and loss of PDGFRB pericyte marker in the precuneus and parietal white matter in Alzheimer's disease. J Cereb Blood Flow Metab. 2018;38:103-15.

60. Park L, Zhou J, Zhou P, Pistick R, El Jamal S, Younkin L, Pierce J, Arreguin A, Anrather J, Younkin SG, et al. Innate immunity receptor CD36 promotes cerebral amyloid angiopathy. Proc Natl Acad Sci U S A. 2013;110:3089-94.

61. Verbeek MM, Van Nostrand WE, Otte-Holler I, Wesseling P, De Waal RM. Amyloid-beta-induced degeneration of human brain pericytes is dependent on the apolipoprotein E genotype. Ann N Y Acad Sci. 2000;903:187-99.

62. Wilhelmus MM, Otte-Holler I, Davis J, Van Nostrand WE, de Waal RM, Verbeek MM. Apolipoprotein E genotype regulates amyloid-beta cytotoxicity. J Neurosci. 2005;25:3621-7.

63. Bruinsma IB, Wilhelmus MM, Kox M, Veerhuis $R$, de Waal RM, Verbeek MM Apolipoprotein E protects cultured pericytes and astrocytes from D-Abeta(140)-mediated cell death. Brain Res. 2010:1315:169-80.

64. Hultman K, Strickland S, Norris EH. The APOE varepsilon4/varepsilon4 genotype potentiates vascular fibrin(ogen) deposition in amyloid-laden vessels in the brains of Alzheimer's disease patients. J Cereb Blood Flow Metab. 2013;33:1251-8.

65. Zonneveld HI, Goos JD, Wattjes MP, Prins ND, Scheltens P, van der Flier WM Kuijer JP, Muller M, Barkhof F. Prevalence of cortical superficial siderosis in a memory clinic population. Neurology. 2014;82:698-704.

66. Cacciottolo M, Christensen A, Moser A, Liu J, Pike CJ, Smith C, LaDu MJ, Sullivan PM, Morgan TE, Dolzhenko E, et al. The APOE4 allele shows opposite sex bias in microbleeds and Alzheimer's disease of humans and mice. Neurobiol Aging. 2016;37:47-57.

67. Esiri MM, Joachim C, Sloan C, Christie S, Agacinski G, Bridges LR, Wilcock GK, Smith AD. Cerebral subcortical small vessel disease in subjects with pathologically confirmed Alzheimer disease: a clinicopathologic study in the Oxford project to investigate memory and ageing (OPTIMA). Alzheimer Dis Assoc Disord. 2014;28:30-5.

68. Rannikmae K, Kalaria RN, Greenberg SM, Chui HC, Schmitt FA, Samarasekera N, Al-Shahi Salman R, Sudlow CL. APOE associations with severe CAAassociated vasculopathic changes: collaborative meta-analysis. J Neurol Neurosurg Psychiatry. 2014;85:300-5.

69. Shinohara M, Murray ME, Frank RD, Shinohara M, DeTure M, Yamazaki $Y$, Tachibana M, Atagi Y, Davis MD, Liu CC, et al. Impact of sex and APOE4 on 
cerebral amyloid angiopathy in Alzheimer's disease. Acta Neuropathol. 2016; 132:225-34

70. Fryer JD, Simmons K, Parsadanian M, Bales KR, Paul SM, Sullivan PM, Holtzman DM. Human apolipoprotein E4 alters the amyloid-beta 40:42 ratio and promotes the formation of cerebral amyloid angiopathy in an amyloid precursor protein transgenic model. J Neurosci. 2005;25:2803-10.

Ready to submit your research? Choose BMC and benefit from:

- fast, convenient online submission

- thorough peer review by experienced researchers in your field

- rapid publication on acceptance

- support for research data, including large and complex data types

- gold Open Access which fosters wider collaboration and increased citations

- maximum visibility for your research: over $100 \mathrm{M}$ website views per year

At BMC, research is always in progress.

Learn more biomedcentral.com/submissions 